encouraged different staphylococci, which may not have been sensitive. The antibiotic treatment, particularly the topical application, probably also changed the phage types. This subject will be discussed in a second paper. Nevertheless, in spite of the influence of these two factors the same phage type was isolated throughout most of the year in seven cases. Also, half the patients who had two or more attacks of clinical sepsis had the same phage type of staphylococci present in subsequent attacks. It seems therefore that the most likely source of the staphylococcus causing a second attack of clinical sepsis was a reservoir site on the patient, in which the same staphylococcus remained after the previous infection. Such reservoir sites were the eczematous areas or the nasal vestibule. The role of the nasal vestibule is emphasized by the fact that on 60 occasions nose and skin swabs both showed staphylococci, and in 55 of these the same phage type was present at both sites.

Though the incidence of a history of infective lesions in the family seemed high, control patients showed a similar incidence. Nevertheless, the fact that the same phage type of staphylococcus was often present in swabs from the family contacts suggests that such contacts may also be a source of the infecting staphylococcus.

\section{STREPTOCOCCI}

Streptococci were isolated less often than staphylococci, but, nevertheless, were present on some occasions in 13 out of 20 cases. In only seven cases were streptococci present more than once, and the same serological type of streptococcus was never found in subsequent attacks of clinical sepsis. Streptococci probably cause isolated attacks of secondary infection and are not likely to settle on the skin in a reservoir site. The association of streptococci of the same serological type in throat swabs of the patients and family contacts suggests that the streptococci come from sources other than the skin itself, and if streptococci are present in subsequent attacks then they too have reached the skin from outside sources and are usually of a different serological type.

\section{ASPECTS OF ANTIBIOTIC TREATMENT}

Though we do not intend to discuss treatment here the use of neomycin and sodium fusidate incorporated in steroid applications seems open to criticism. In the case of staphylococci these steroid applications might control some acute attacks of clinical sepsis when this organism is sensitive to the antibiotics, but with regard to preventing further attacks it seems that there is a ready acquisition of strains resistant to these drugs which is difficult to control. Furthermore, these resistant strains may spread to other family members. Streptococci are also highly resistant to neomycin and gentamicin and moderately resistant to sodium fusidate so that this type of clinical sepsis would also not be avoided by their use.

We thank Dr. M. T. Parker for the serological typing of the streptococci and for his advice. We also thank Professor W. A. Gillespie for his encouragement, and Dr. J. L. Burton for help with the presentation.

\section{References}

1 Blair, J. E., and Williams, R. E. O., Bulletin of the World Health Organization, 1961, 24, 771 .

${ }^{2}$ Subcommittee on Phage Typing of Staphylococci, International fournal of Systeinutic Bacteriology, 1971, 21, 167.

\title{
Plasma Corticotrophin Levels in Addison-Schilder's Disease
}

\author{
LESLEY H. REES， D. B. GRANT， J. WILSON
}

\section{Introduction}

Schilder's disease ${ }^{1}$ is characterized by non-inflammatory destruction of white matter but its exact nature is uncertain. In one form of the disease, a sex-linked condition, diffuse cerebral sclerosis is associated with adrenocortical insufficiency (AddisonSchilder's disease). ${ }^{2}$ Steroid replacement does not modify the fatal neurological course, and the response to exogenous corticotrophin (ACTH) may be impaired or absent. We are unaware of any data on circulating endogenous ACTH levels in such patients and report here the results of plasma ACTH assays in five boys with the disorder and in a symptom-free brother of one of them.

\section{Patients and Methods}

The disorder was characterized by dementia, cortical blindness or deafness, pyramidal signs, and ataxia. The clinical features (see table I) are detailed elsewhere. ${ }^{3}$ Two boys (cases 1 and 2 ) had abnormal skin pigmentation. None had received steroids.

Urinary 17-hydroxycorticoids (17-OHCS) and 17-oxosteroids were measured by Cathro's ${ }^{4}$ methods, and plasma cortisol by competitive protein binding before and 30 minutes after an intravenous injection of $0.25 \mathrm{mg}$ tetracosactrin. ${ }^{5}$ Plasma ACTH was estimated in samples collected into heparinized plastic tubes, enzymatic degradation being prevented. ${ }^{6}$ Two antisera were used for the radioimmunoassay, one against the active $\mathrm{N}$-terminal part of the ACTH molecule and the other against the inactive $\mathrm{C}$ terminus. ${ }^{7}$ Measurements were also made 
TABLE I-Clinical Features and Results of Adrenal Function Tests

\begin{tabular}{|c|c|c|c|c|c|c|c|}
\hline \multirow{2}{*}{$\begin{array}{l}\text { Case } \\
\text { No. }\end{array}$} & \multirow{2}{*}{$\begin{array}{c}\text { Clinical } \\
\text { Presentation }\end{array}$} & \multirow{2}{*}{$\begin{array}{l}\text { Age at } \\
\text { Onset } \\
\text { (Years) }\end{array}$} & \multirow{2}{*}{$\begin{array}{c}\text { Age at } \\
\text { Investigation } \\
\text { (Years) }\end{array}$} & \multicolumn{2}{|c|}{$\begin{array}{l}\text { Plasma Cortisol } \\
(\mathrm{nmol} / \mathrm{l})\end{array}$} & \multirow{2}{*}{$\begin{array}{c}\text { Urinary } \\
\text { 17-oxosteroids } \\
(\mu \mathrm{mol} / 24 \mathrm{~h})\end{array}$} & \multirow{2}{*}{$\begin{array}{c}\text { Urinary } \\
17-\mathrm{OHCS} \\
(\mu \mathrm{mol} / 24 \mathrm{~h})\end{array}$} \\
\hline & & & & $\begin{array}{c}\text { Before } \\
\text { Tetracosactrin }\end{array}$ & $\begin{array}{c}\text { After } \\
\text { Tetracosactrin }\end{array}$ & & \\
\hline $\begin{array}{l}1 \\
2 \\
3 \\
4 \\
5 \\
6^{*}\end{array}$ & $\begin{array}{l}\text { Blindness/dementia } \\
\text { Blindness } \\
\text { Deafness/dementia } \\
\text { Dementia/ataxia } \\
\text { Vomiting/dementia } \\
\text { No symptoms }\end{array}$ & $\begin{array}{r}6 \cdot 7 \\
6 \cdot 5 \\
7 \cdot 7 \\
8 \cdot 0 \\
10 \cdot 0\end{array}$ & $\begin{array}{r}6 \cdot 7 \\
7 \cdot 5 \\
9 \cdot 0 \\
10 \cdot 6 \\
12 \cdot 0 \\
4 \cdot 0\end{array}$ & $\begin{array}{l}524 \\
541 \\
367 \\
340 \\
243 \\
409\end{array}$ & $\begin{array}{l}762 \\
831 \\
508 \\
455 \\
166 \\
343\end{array}$ & $\begin{array}{r}4 \cdot 2 \\
10 \cdot 4 \\
6 \cdot 2 \\
19 \cdot 0 \\
7 \cdot 6\end{array}$ & $\begin{array}{r}22 \cdot 9 \\
21 \cdot 9 \\
7 \cdot 6 \\
29 \cdot 1 \\
26 \cdot 0\end{array}$ \\
\hline
\end{tabular}

*Brother of case 5 .

Conversion: SI to Traditional Units-Plasma cortisol: $1 \mathrm{nmol} / 1 \approx 0.0362 \mu \mathrm{g} / 100 \mathrm{ml}$. Urinary 17 -oxosteroids and $17-\mathrm{OHCS}: 1 \mu \mathrm{mol} / 24 \mathrm{~h} \approx 0.29 \mathrm{mg} / 24 \mathrm{~h}$.

using a sensitive cytochemical bioassay in which changes in redox potential of the zona reticularis of guinea-pig adrenals are compared with changes induced by an ACTH standard. ${ }^{8}$ Plasma $\beta_{h}$-melanocytestimulating hormone $\left(\beta_{h}-M S H\right)$ was measured by radioimmunoassay using an antiserum against impure porcine ACTH presumably contaminated with $\beta$-MSH. ${ }^{9}$

No patient was unduly distressed at venepuncture and we do not believe that our results can be attributed to stress.

\section{Results}

In all patients the urinary $17-\mathrm{OHCS}$ and 17 -oxosteroids were in the normal range ${ }^{4}$ (table I). The two brothers (cases 5 and 6 ) showed no plasma cortisol response to tetracosactrin, cases 3 and 4 showed subnormal responses, and cases 1 and 2 normal responses (table I). All cases had normal basal cortisol values. ${ }^{5}$ Immunoassay ACTH values (table II) were raised in all cases. Bioassay values in case 1 were also grossly abnormal. The patient showed a consistent nyctohemeral variation in plasma $\mathrm{ACTH}$, and low bioactive values were obtained after three days on dexamethasone. Elevated ACTH levels occurred 24 hours after dexamethasone was stopped. Case 4 also showed a nyctohemeral variation in plasma ACTH. The single determination of $\beta_{\mathrm{h}}-\mathrm{MSH}$ in case 1 showed a level of 612 (normal 6-36) $\mathrm{ng} / \mathrm{l}$.

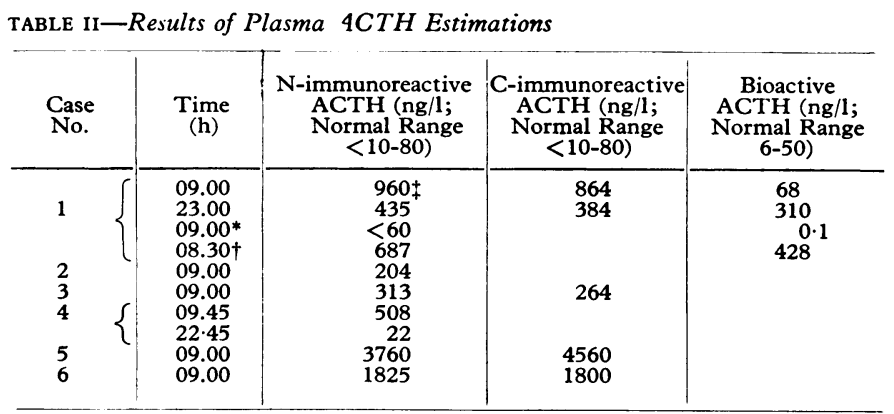

* On dexamethasone $8 \mathrm{mg} /$ day.

Dexamethasone stopped for 24 hours.

$\ddagger$ Immunoreactive $\beta$-MSH level $612 \mathrm{ng} / 1$.

\section{Discussion}

The plasma ACTH levels were closely similar to those found in adults with adrenocortical insufficiency. ${ }^{10}$ The nyctohemeral variations and effect of dexamethasone observed indicate that hypothalamic control of ACTH secretion may sometimes be preserved. Pigmentation and raised $\beta_{\mathrm{h}} \mathrm{MSH}$ are features of adult primary adrenocortical insufficiency, ${ }^{11}$ and from our results immunoreactive $\beta_{h}-\mathrm{MSH}$ may also be raised in AddisonSchilder's disease.

Plasma ACTH levels measured by the two antisera showed good agreement. Though the bioassay values were consistently lower than the immunoassay results, such dissociations are well recognized, ${ }^{12}$ and our results indicate that the adrenal atrophy in Addison-Schilder's disease cannot be attributed to the secretion of an inactive form of ACTH. The cause of the disorder is still unknown, but since fibroblasts from affected patients accumulate excessive amounts of cholesterol ${ }^{13}$ it may be metabolic.

Estimation of plasma ACTH may be of value when AddisonSchilder's disease is suspected. A feature of the condition is the apparently mild nature of the adrenal disorder in some patients. In our patients, urinary steroid excretion was in the low-normal range, and two boys showed normal plasma cortisol responses to tetracosactrin. Thus estimation of plasma ACTH may be a more sensitive method for detecting adrenal disease, and our findings in the symptom-free brother of case 5 suggest that it may help in establishing the diagnosis before neurological symptoms develop.

We thank Dr. J. J. H. Gilkes for the $\beta_{\mathrm{h}}-\mathrm{MSH}$ determination, Dr. J. G. Ratcliffe for ACTH measurements in two patients, and Dr. E. M. Brett for allowing us to study one of his patients.

\section{References}

1 Schilder, P., Zeitschrift für die gesamte Neurologie und Psychiatrie, 1912, $10,1$.

2 Siemerling, E., and Creutzfeldt, H. G., Archiv für Psychiatrie und Nervenkrankheiten, 1923, 68, 217.

3 Wilson, J., and Jamieson, D. In preparation.

${ }^{4}$ Cathro, D. M., in Paediatric Endocrinology, ed. D. Hubble, p. 232. Oxford, Blackwell, 1969.

${ }^{5}$ Barnes, N. D., et al., Archives of Disease in Childhood, 1972, 47, 66.

${ }^{6}$ Rees, L. H., et al., Endocrinology, 1971, 89, 254.

7 Ratcliffe, J. G., et al., Clinical Endocrinology, 1972, 1, 27.

${ }^{8}$ Holdaway, I. M., et al., Clinical Endocrinology, 1974, 3, 329.

${ }^{9}$ Gilkes, J. J. H., et al., Fournal of Clinical Endocrinology. In press.

10 Besser, G. M., et al., British Medical fournal, 1971, 1, 374.

11 Abe, K., et al., fournal of Clinical Investigation, 1969, 48, 1580

12 Besser, G. M., et al., fournal of Clinical Endocrinology, 1971, 32, 595.

${ }^{13}$ Burton, B. K., and Nadler, H. L., Pediatric Research, 1974, 8, 170. 